\title{
Front Matter: Volume 11216
}

, "Front Matter: Volume 11216," Proc. SPIE 11216, Multiscale Imaging and Spectroscopy, 1121601 (4 March 2020); doi: 10.1117/12.2569576

SPIE. Event: SPIE BiOS, 2020, San Francisco, California, United States 


\title{
PROGRESS IN BIOMEDICAL OPTICS AND IMAGING

\section{Multiscale Imaging and Spectroscopy}

\author{
Paul J. Campagnola \\ Kristen C. Maitland \\ Darren M. Roblyer \\ Editors
}

1-2 February 2020

San Francisco, California, United States

Sponsored and Published by

SPIE 
The papers in this volume were part of the technical conference cited on the cover and title page. Papers were selected and subject to review by the editors and conference program committee. Some conference presentations may not be available for publication. Additional papers and presentation recordings may be available online in the SPIE Digital Library at SPIEDigitalLibrary.org.

The papers reflect the work and thoughts of the authors and are published herein as submitted. The publisher is not responsible for the validity of the information or for any outcomes resulting from reliance thereon.

Please use the following format to cite material from these proceedings:

Author(s), "Title of Paper," in Multiscale Imaging and Spectroscopy, edited by Paul J. Campagnola, Kristen C. Maitland, Darren M. Roblyer, Proceedings of SPIE Vol. 11216 (SPIE, Bellingham, WA, 2019) Seven-digit Article CID Number.

ISSN: 1605-7422

ISSN: 2410-9045 (electronic)

ISBN: 9781510631953

ISBN: 9781510631960 (electronic)

Published by

SPIE

P.O. Box 10, Bellingham, Washington 98227-0010 USA

Telephone +1 3606763290 (Pacific Time) · Fax +1 3606471445

SPIE.org

Copyright (c) 2020, Society of Photo-Optical Instrumentation Engineers.

Copying of material in this book for internal or personal use, or for the internal or personal use of specific clients, beyond the fair use provisions granted by the U.S. Copyright Law is authorized by SPIE subject to payment of copying fees. The Transactional Reporting Service base fee for this volume is $\$ 21.00$ per article (or portion thereof), which should be paid directly to the Copyright Clearance Center (CCC), 222 Rosewood Drive, Danvers, MA 01923. Payment may also be made electronically through CCC Online at copyright.com. Other copying for republication, resale, advertising or promotion, or any form of systematic or multiple reproduction of any material in this book is prohibited except with permission in writing from the publisher. The CCC fee code is $1605-$ $7422 / 20 / \$ 21.00$.

Printed in the United States of America by Curran Associates, Inc., under license from SPIE.

Publication of record for individual papers is online in the SPIE Digital Library.

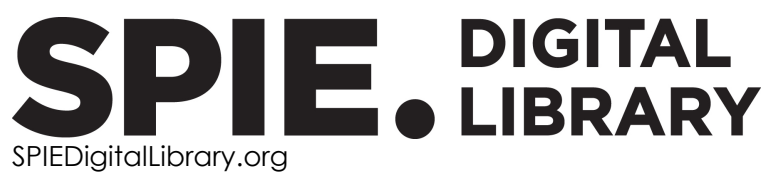

Paper Numbering: Proceedings of SPIE follow an e-First publication model. A unique citation identifier (CID) number is assigned to each article at the time of publication. Utilization of CIDs allows articles to be fully citable as soon as they are published online, and connects the same identifier to all online and print versions of the publication. SPIE uses a seven-digit CID article numbering system structured as follows:

- The first five digits correspond to the SPIE volume number.

- The last two digits indicate publication order within the volume using a Base 36 numbering system employing both numerals and letters. These two-number sets start with $00,01,02,03,04$, 05, 06, 07, 08, 09, 0A, OB ... 0Z, followed by 10-1Z, 20-2Z, etc. The CID Number appears on each page of the manuscript. 


\title{
Contents
}

\author{
$\checkmark \quad$ Authors \\ vii Conference Committee
}

IMAGING AND SPECTROSCOPY THROUGH TIME AND SPACE: LONGITUDINAL STUDIES

$11216 \mathrm{OH} \quad$ Key features in the optical properties of tissue during and after radiofrequency ablation [11216-16]

MULTISCALE IMAGING IN ONCOLOGY

11216 OP Heterogeneity of mitochondria morphology in breast cancer cells [11216-24]

EMERGING SOURCES OF MULTISCALE IMAGING CONTRAST

$112160 \mathrm{U}$ Estimating paired-agent uptake in altered tumor vasculature using MRI-coupled fluorescence tomography [11216-28]

POSTER SESSION

$112160 \mathrm{~W}$ Optical simulations for determining efficacy of new light source designs for excitation-scanning high-speed hyperspectral imaging systems [11216-30]

1121610 Femtosecond third-order sum frequency and four-wave mixing imaging [11216-34]

1121611 Dynamic range enhancement for diffuse optical spectroscopy in breast scanning applications [11216-35]

1121614 Characteristic of leukocytes Raman spectrum in single-cell levels based on wavelet transform [11216-38] 
Proc. of SPIE Vol. 11216 1121601-4 Downloaded From: https://www.spiedigitallibrary.org/conference-proceedings-of-spie on 26 Apr 2023
Terms of Use: https://www.spiedigitallibrary.org/terms-of-use 


\section{Authors}

Numbers in the index correspond to the last two digits of the seven-digit citation identifier (CID) article numbering system used in Proceedings of SPIE. The first five digits reflect the volume number. Base 36 numbering is employed for the last two digits and indicates the order of articles within the volume. Numbers start with 00, 01, 02, 03, 04, 05, 06, 07, 08, 09, OA, OB...0Z, followed by 10-1Z, 20-2Z, etc.

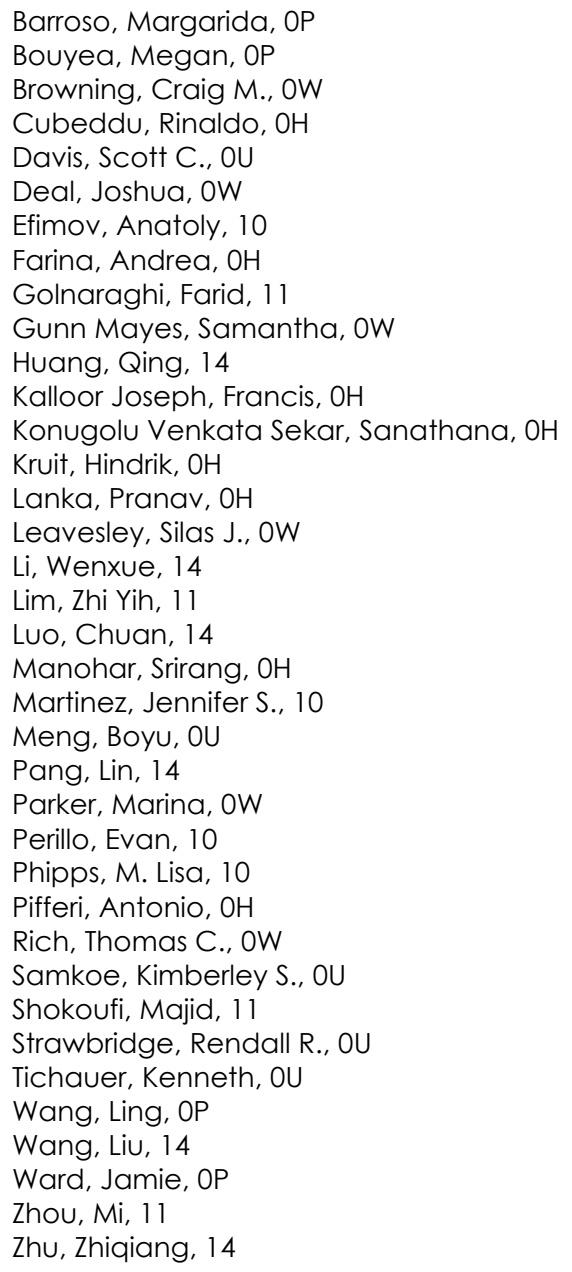


Proc. of SPIE Vol. 11216 1121601-6 Downloaded From: https://www.spiedigitallibrary.org/conference-proceedings-of-spie on 26 Apr 2023
Terms of Use: https://www.spiedigitallibrary.org/terms-of-use 


\title{
Conference Committee
}

\author{
Symposium Chairs
}

Jennifer K. Barton, The University of Arizona (United States)

Wolfgang Drexler, Medizinische Universität Wien (Austria)

Program Track Chairs

Brian Jet-Fei Wang, Beckman Laser Institute and Medical Clinic,

University of California, Irvine (United States)

Eva Sevick, The University of Texas Health Science Center at Houston (United States)

\section{Conference Chairs}

Paul J. Campagnola, University of Wisconsin-Madison (United States)

Kristen C. Maitland, Texas A\&M University (United States)

Darren M. Roblyer, Boston University (United States)

\section{Conference Program Committee}

Ji-Xin Cheng, Boston University (United States)

Kevin W. Eliceiri, University of Wisconsin-Madison (United States)

Irene Georgakoudi, Tufts University (United States)

Anita Mahadevan-Jansen, Vanderbilt University (United States)

Andrew M. Rollins, Case Western Reserve University (United States)

Melissa C. Skala, University of Wisconsin-Madison (United States)

Alex J. Walsh, Texas A\&M University (United States)

\section{Session Chairs}

$1 \quad$ Nano-Based Imaging

Darren M. Roblyer, Boston University (United States)

2 Bridging Spatial Scales: From Nano to Micro to Meso Scale Imaging

Paul J. Campagnola, University of Wisconsin-Madison (United States)

3 Omniscale Imaging

Kristen C. Maitland, Texas A\&M University (United States)

4 Imaging and Spectroscopy through Time and Space: Longitudinal Studies

Darren M. Roblyer, Boston University (United States) 
5 Multiscale Imaging in Oncology

Paul J. Campagnola, University of Wisconsin-Madison (United States)

6 Emerging Sources of Multiscale Imaging Contrast

Kristen C. Maitland, Texas A\&M University (United States) 